\title{
Factors related to hospital nurse intention to leave: Does striving for work-life balance and sense of coherence affect wishes to stay in the organization?
}

\author{
Maki Matsuo, Eiko Suzuki, Yuko Takayama
}

\begin{abstract}
The aim of this study is to identify relationships between striving for work-life balance (S-WLB), sense of coherence (SOC), and intention to leave among hospital nurses. In August of 2017, we conducted a self-administered questionnaire survey to 2239 nurses at nine public hospitals. The questionnaire included demographic factors, work environmental factors, organizational factors, striving for worklife balance, a 13-item SOC, the Maslach Burnout Inventory, and intention to leave. We carried out a multiple regression analysis with intention to leave as the dependent variable and others as independent variables. We obtained valid responses from 1368 full-time employed nurses $(61.1 \%)$. The mean age of respondents was $36.38 \pm 10.18$ years, and the length of clinical experience 13.4 \pm 9.65 years. The mean total score of the intention to leave was $14.58 \pm 5.09$. As a result of the multiple regression analysis, the $S$ WLB and the SOC were found to be statistically related to the intention to leave even after controlling for the confounding factor of burnout. In addition, the satisfaction of desire level for the actual working assignment at the workplace was a significant independent factor. In this study, the full-time nursing staff had a low intention to leave score when they had a high score in the $S$ WLB and the SOC. It was also found that the level of satisfaction with appointment to a desired assignment is a significant factor in the intention to leave. In establishing an attractive workplace for nursing staff, it is important to create a workplace environment and supports to be able to properly evaluate workplace satisfaction after assignments are made while taking into account individual S-WLB and SOC functions.
\end{abstract}

Keywords- nurses; work-life balance; sense of coherence; intention to leave

\section{INTRODUCTION}

The declining birthrate and aging society that is becoming increasingly acute in Japan is a never before experienced situation here. Securing labor as a productive population is important in this situation, and promotion of a stabilized nursing workforce is considered to ensure the quality of patient care. For the turnover rate of hospital nursing staff in Japan, the full-time nursing staff has been reported as $10.9 \%$ and for new graduate nurses it was $7.8 \%$. It is clear that the turnover rate is higher in urban areas and smaller hospitals [1]. Factors related to turnover and intention to leave are individually determined factors affected by suitability as a nurse [2], self-esteem [3] and for other reasons. Among environmental factors in the workplace, many studies have reported burnout [4,5,6], which is considered an occupational stress syndrome. According to

This work was supported was supported by JSPS KAKENHI Grant Number JP18K10248. previous studies, factors related to ward assignment included: guidance and management framework [7]; lack of colleagues $[8,9]$; absence of support by supervisors [9,10]; atmosphere where it is comfortable to talk [3]; and dissatisfaction with the assigned ward as it is different from what was hoped for [8]. Organizational factors include the organizational climate [11], salary [3], and organizational commitment [12]. In addition, as working hours [7] and work-home life balance [13] are related to the backgrounds of both work and private life, factors related to turnover are becoming increasingly complicated. As a preventive measure to ward against turnover, the Japan Nursing Association [1] started an "employment promotion project by nursing staff with working styles" and has tried to strengthen the work arrangements. In addition, the turnover rate of new graduate nurses was reduced with some effect by measures such as establishing human relationships, carrying out collective training [14,15], and other measures. However, in the last few years the turnover rate has remained unchanged, and among employees the proportion of mental health disorders is the highest at $76.6 \%$ in the medical and welfare occupations [16]. Further, in a labor situation survey of nursing staff, it is reported that overwork and health insecurity remain unchanged [17]. The nursing work environment is extremely busy and irregular, and it is desirable to enable staff to be able to work properly as a resident citizen.

Work-life balance (WLB) is defined as being able to achieve both work and other living conditions in a desired state by oneself [18]. The nurse WLB is related to levels of career maturity [19], burnout [18.], and intention to leave [20], which may lead to job satisfaction, health maintenance, and a declining turnover rate. Therefore, it is desirable to promote WLB. In order to make WLB feasible, it is important to clarify how individuals actually behave for the WLB. By thinking about the relationship between the power to strive for WLB and the intention to leave, we thought that it is possible to avoid strengthening the intention to leave and to continue a professional life.

We also focused on the sense of coherence (SOC), which is the core concept of salutogenesis. It is the ability to maintain health by changing the impact of experiences rather than impairing health even under much stress [21]. Various previous studies $[22,23,24]$ showed that the function of SOC predicts and defuses the tension of mental and physical health, and we thought that the SOC considerations would be effective for turnover prevention. 
We evaluated by examined both the work environment and organizational background based on the previous research [25] which clarified the relationships between striving for WLB, SOC, and intention to leave The aim of this study is to identify suggestions for a reduction of intention to leave the organization among nurses.

\section{METHODS}

\section{A. Participants}

The subjects were 2239 nurses working in 9 national and public hospitals with $99-500$ beds. The authors distributed a self-administered questionnaire survey to the nurses in August, 2017.

\section{B. Measurements}

\section{1) Intention to leave}

The intention to leave was assessed using a 6-item scale developed by Tei-Tominaga [26], which has shown reliability and validity. Each item asked about the participants' thoughts or behaviors related to resignation from their job. Responses were scored on a 4-point scale. The sum of the scores ranges from 6 to 24, with higher total scores indicating a stronger intention to leave. The Cronbach's alpha coefficients in this study were 0.905 . Permission to use the questionnaires has been obtained from developers.

\section{2) Demographic attributes}

Demographic details for gender, age, marital status, parental status, caregiver status, form of the cohabiting family, education, experience as a nurse, occupational assignment, chronic diseases, and confidence in physical strength. Further, details of the attitude to the work, information on suitability as a nurse, feelings as a member of the employing organization, salary satisfaction, family understanding of the work, and ideas of changing and leaving jobs. The responses were scaled as ranging from "not at all" to "very much so" in six grades.

\section{3) Environmental Factors}

Information was collected on the position, working schedule, section of work, ward assignment preferences, presence of someone providing assistance in the workplace, and commuting time. Regarding perceptions of the workplace, details of workplace approval, opportunities to demonstrate abilities, assignment of duties beyond individual capability, satisfaction with welfare benefits, awareness of role in the workplace, cooperation among helping staff at the workplace, ease for medical accidents to occur, cooperation in cases of medical accidents, openness in discussions in the workplace, high turnover rate in the hospital, ease to take holidays according to own wishes, and providing adequate patient care and availability of care supplies. The responses were scaled as ranging from "not at all" to "very much so" in six grades.

\section{4) Striving for work-life balance}

The striving for work-life balance was assessed using the striving for work-life balance (S-WLB) scale developed by the chief author, which has shown reliability and validity (not published data). It consists of 11 items, in 2 subscales, consisting of 6 items of consultation ability in seeking support and 5 items of self-control. The S-WLB was rated on a 6-point scale, with the sum of the scores from 11 to 66 , with the higher total score indicating a higher S-WLB.

\section{5) Sense of coherence}

The Japanese version of the SOC-13, which was described and verified for reliability and validity by Yamazaki [27] and is based on the original scale of Antonovsky [21] was used. It comprises the following subscales: comprehensibility, manageability, and meaningfulness. The SOC score was rated on a 7-point scale. The sum of the scores (SOC scale score) totaling from 13 to 91 , with the higher total score showing a stronger SOC. Permission to use the scale questionnaire was obtained from the developers and copyright-holder.

\section{6) Maslach Burnout Inventory - General Survey}

The Japanese version of the Maslach Burnout Inventory General Survey (MBI-GS), which was described and verified for reliability and validity by Kitaoka-Higashiguchi [28] and is based on the original scale of Maclach [29], was used. It comprises the following subscales: exhaustion, cynicism, and professional efficacy. The Japanese MBI-GS has 16-items and responses options from never to every day. Permission to use the scale questionnaire was obtained from the Japanese version developers and copyright-holder.

\section{7) Organizational Factors}

The questions addressed organizational factors: size of the city of the hospital location, type of hospital, average number of hospitalization days, and number of hospital beds.

\section{Procedures}

The questionnaires were mailed to the hospitals, and the directors of the nursing departments were asked to distribute these to the potential participants and to provide collection bags for the completed questionnaires. The collection bags for the questionnaires were made available at the hospitals for 2 weeks after which the collected questionnaires were forwarded to the author by the directors.

\section{Statistical analysis}

First, for the participant demographic characteristics, the frequency, mean total of intention to leave scores, and standard deviations of the variables were calculated. The relationships between the mean total intention to leave scores and other factors were determined. The tests of significance were the $t$ test and one-way ANOVA. For the variables with interval scales, the correlation coefficients with the mean total intention to leave scores were calculated. Second, to establish the relevant factors of the intention to leave, a stepwise multiple regression analysis for intention to leave scores was conducted, using independent variables where the statistical significance was at $P<0.2$. For questions with more than three choices: education, the overtime per month, the ward assignment preference, type of hospital, average number of hospitalization days, and size of the city where the hospital is located were converted into dummy variables. Other responses were transformed into dichotomous ratings in the multivariate analysis. We confirmed that VIF is 10 or less in multicollinearity. For the statistical analyses, IBM SPSS Statistics (v. 24.0; IBM Corporation, Armonk, NY, USA) was used. 


\section{E. Ethical considerations}

The cooperation of the directors of the nursing service departments at hospitals was obtained by explaining the purpose of the study in writing. The study objectives and methods were explained to the participating nurse supervisors in writing: all respondents were informed that their anonymity would be protected, that their participation or withdrawal was as determined by their own free will, and that refusal to participate or withdrawal of consent would not result in any negative consequences. At the beginning of the questionnaire form, there was a check box to show agreement or disagreement with participation in the research, it was considered to show agreement to participate when the agree box was marked. The protocol for this study was approved by the Ethics Review Committee of the International University Health and Welfare (No.17-Ig-47, July 2017).

\section{RESULTS}

\section{A. Response rate and the mean total Intention to leave score}

The authors distributed questionnaires to 2239 nurses, and collected $1739(77.6 \%)$ responses. Of these, responses from $1494(66.7 \%)$ nurses were determined as valid responses. There was a statistically significant difference in the intention to leave score with the job type and kind of employment, 1368 full-time nurses $(61.1 \%)$ were analyzed for the form of employment. Participating hospitals were nine public hospitals. There was a significant difference $(\mathrm{p}<0.01)$ in the mean total intention to leave scores in some hospitals. The results of the multiple regression analysis of the nine hospitals were compared with the eight hospitals after excluding hospitals with high or low intention to leave scores. Since items with high rates of explanation were for similar variables, all the facilities were analyzed. The mean total intention to leave score was $14.58 \pm 5.09$.

\section{B. Participant demographic data}

The mean age of the participant was $36.4 \pm 10.2$ years and the experience as a nurse was $13.4 \pm 9.7$ years, showing no correlation with the intention to leave score (Table 3). The nurses in 2nd and 3rd years had the highest intention to leave scores (Table 1). The 1266 female nurses (93.2\%) and 97 male nurses $(6.5 \%)$, and the 1236 nurses $(92.3 \%)$ and 103 midwives $(7.5 \%)$ did not significantly differ in the intention to leave (Table1).

\section{Personal factors and the total intention to leave score}

The participant demographic data and the mean total intention to leave scores are shown in Table1. The statistically significant variables were: age, having a spouse and children $(<$ 7 years), experience as a nurse, chronic disease, and confidence in physical strength (all, $P<0.01$ ). In addition, the education variable reached statistical significant value $(0.05<P<0.2)$.
D. Work environmental factors and the total intention to leave score

The participant workplace environmental factors and the mean total intention to leave scores are shown in Table2. The statistically significant variables were: overtime per month, ward assignment preference, having coworkers who will provide support in the workplace (other occupation, junior, senior, or supervisor), and enough care supplies (all, $P<0.01$ ). Variables that reached statistically significant values were position $(0.05<P<0.01)$, shift type, and coworkers who will provide support in the workplace $(0.05<P<0.2)$.

\section{E. Correlation between the continuous variables and the total intention to leave score}

The correlation coefficient for S-WLB $(r=-0.39, \mathrm{P}<0.01)$ and SOC $(r=-0.45, \mathrm{P}<0.01)$ showed a negative intermediate correlation with the total intention to leave score. For MBI-GS, exhaustion showed a positive intermediate correlation $(\mathrm{r}=0.46$, $\mathrm{P}<0.01)$ as did cynicism $(\mathrm{r}=0.57, \mathrm{P}<0.01)$. The actual proportion of work life vs non-work life percentage showed a weak positive correlation $(\mathrm{r}=0.21, \mathrm{P}<0.01)$, and as the proportion of work vs private life increased, the intention to leave score was higher (Table3)

\section{F. Way of thinking about work and the total intention to leave score}

The way of thinking about the work and the total intention to leave scores are shown in Table4. The statistically significant variables were: suitability as a nurse, feeling of being a part of the organization, salary satisfaction, family understanding towards work, and perceived hardship in the life after resignation (all, $P<0.01$ ).

\section{$G$. Perception of the workplace and the total intention to leave score}

Perception of the workplace and the total intention to leave scores are shown in Table5. The statistically significant variables were 11 items: approval in the workplace, opportunities to demonstrate ability, benefits good, working with role consciousness, cooperation in the workplace, medical accidents easy to occur in hospital, security in case of medical accidents, openness in discussions in the workplace, high turnover rate in the hospital, ease of obtaining desired holiday, and providing sufficient patient care (all, $P<0.01$ ).

\section{H. Organizational characteristic and the total intention to leave score}

The participant organizational factors and the mean total intention to leave scores are shown in Table6. There are 4 general hospitals, 2 regional medical care hospitals, and 3 advanced treatment hospitals in this survey. The average number of days of hospitalization was 1 facility with 10 days or less, 5 facilities for 11 to 15 days, and 3 facilities with 16 days or more, with significant differences observed $(P<0.01)$. 
Table 1. Demographic factors and total intention to leave score

\begin{tabular}{|c|c|c|c|c|c|c|}
\hline \multirow[t]{2}{*}{ Demographic factors } & & \multicolumn{2}{|c|}{ Participants } & \multicolumn{3}{|c|}{ Total Intention to leave score } \\
\hline & & $\mathrm{N}$ & $(\%)$ & Mean & $\mathrm{SD}$ & \\
\hline \multirow[t]{3}{*}{ Gender } & Male & 97 & 7.1 & 13.95 & 5.59 & \\
\hline & Female & 1266 & 90.1 & 14.61 & 5.04 & \\
\hline & No answer & 5 & 0.4 & - & - & \\
\hline \multirow{8}{*}{ Age } & $\leq 24$ years & 186 & 13.6 & 14.44 & 5.56 & $* *$ \\
\hline & $25-29$ years & 255 & 18.6 & 15.59 & 5.02 & \\
\hline & 30 - 34years & 158 & 11.5 & 14.77 & 4.93 & \\
\hline & 35 - 39 years & 200 & 14.6 & 15.10 & 5.26 & \\
\hline & $40-44$ years & 217 & 15.9 & 14.03 & 4.96 & \\
\hline & 45 - 49 years & 174 & 12.7 & 14.09 & 4.94 & \\
\hline & $50-54$ years & 110 & 8.0 & 14.48 & 4.28 & \\
\hline & $\geq 55$ years & 68 & 5.0 & 12.32 & 4.87 & \\
\hline \multirow[t]{3}{*}{ Spouse } & Yes & 659 & 51.1 & 14.24 & 4.94 & $* *$ \\
\hline & No & 699 & 48.2 & 14.85 & 5.16 & \\
\hline & No answer & 10 & 0.7 & - & - & \\
\hline \multirow[t]{3}{*}{ Child living together $(\leq 7$ years $)$} & Yes & 214 & 15.6 & 13.58 & 4.96 & $* *$ \\
\hline & No & 1076 & 84.5 & 14.76 & 5.06 & \\
\hline & No answer & 51 & 3.7 & - & - & \\
\hline \multirow[t]{3}{*}{ Child living together ( $\geq 7$ years ) } & Yes & 380 & 28.0 & 14.18 & 4.81 & \\
\hline & No & 910 & 72.0 & 14.72 & 5.16 & \\
\hline & No answer & 78 & 5.7 & - & - & \\
\hline \multirow[t]{3}{*}{ Care giver living together } & Yes & 36 & 2.6 & 13.61 & 4.88 & \\
\hline & No & 1254 & 91.7 & 14.59 & 5.07 & \\
\hline & No answer & 78 & 5.7 & - & - & \\
\hline \multirow[t]{6}{*}{ Education } & Vocational school of nursing & 932 & 68.1 & 14.40 & 5.00 & $\dagger$ \\
\hline & Nursing junior college & 87 & 6.4 & 14.22 & 4.73 & \\
\hline & University of nursing & 300 & 21.9 & 15.16 & 5.33 & \\
\hline & Graduated school of nursing & 16 & 1.2 & 14.56 & 5.76 & \\
\hline & $\begin{array}{l}\text { Five years of consistent nursing } \\
\text { education }\end{array}$ & 18 & 1.3 & 16.50 & 4.57 & \\
\hline & No answer & & 15 & 1.1 & - & - \\
\hline \multirow[t]{6}{*}{ Experience as a nurse } & 1 years & 90 & 6.6 & 12.32 & 5.90 & $* *$ \\
\hline & $2-3$ years & 161 & 11.8 & 15.21 & 5.11 & \\
\hline & 4. 5.6 years & 200 & 14.6 & 15.01 & 4.88 & \\
\hline & 7. 8. 9. 10 years & 178 & 13.0 & 14.88 & 4.80 & \\
\hline & $11-20$ years & 409 & 30.0 & 14.77 & 5.07 & \\
\hline & $\geq 21$ years & 303 & 24.1 & 13.81 & 4.85 & \\
\hline \multirow[t]{2}{*}{ Occupation } & Nurse & 1263 & 92.3 & 14.62 & 5.09 & \\
\hline & Midwives & 103 & 7.5 & 14.08 & 5.05 & \\
\hline \multirow[t]{3}{*}{ Chronic disease } & Yes & 179 & 13.1 & 14.96 & 5.20 & $* *$ \\
\hline & No & 1175 & 85.9 & 14.52 & 5.08 & \\
\hline & No answer & 14 & 0.4 & - & - & \\
\hline \multirow[t]{5}{*}{ Confidence in physical strength } & Not confidence & 88 & 6.4 & 17.50 & 4.84 & $* *$ \\
\hline & Not very confidence & 563 & 41.2 & 15.24 & 4.82 & \\
\hline & Somewhat confidence & 604 & 44.2 & 13.74 & 5.09 & \\
\hline & Have confidence & 105 & 7.7 & 13.70 & 5.65 & \\
\hline & No answer & 8 & 0.6 & - & - & \\
\hline
\end{tabular}

$\dagger 0.05<P<0.2$, ** $P<0.01$, according to the $t$ - test and one - way ANOVA. SD, standard deviation.

\section{Factors related to intention to leave determined with the} stepwise multiple regression analysis

The degrees of freedom adjusted coefficient of determination was $45 \%$. The multiple regression analysis identified factors that were related to intention to leave as MBI-GS (cynicism) ( $\beta=0.30)$, the ward assignment preference $(\beta=-0.19)$, the SOC $(\beta=-0.12)$, MBI-GS (exhaustion) $(\beta=0.11)$. As for the desired assignment, the nurses who were satisfied with the assignment or did not desire an assignment had lower intention to leave mean scores than nurses who were dissatisfied with the assignment or did not desire how they had been assigned. For individual factors, nurses who have high SOC and S-WLB total mean scores showed a low intention to leave. For environmental factors, the perception of nurses that secured feelings arise when a medical accident happens $(\beta=-$ $0.07)$ and that the workplace offers an opportunity for open discussion $(\beta=-0.07)$ showed a low intention to leave. In addition, a perception that the hospital has a high turnover rate 
Table 2. Environmental factors and the total intention to leave score

$\mathrm{N}=1368$

\begin{tabular}{|c|c|c|c|c|c|c|}
\hline \multirow{2}{*}{ Environmental factors } & & \multicolumn{2}{|c|}{ Participants } & \multicolumn{3}{|c|}{ Total Intention to leave score } \\
\hline & & $\mathrm{N}$ & $(\%)$ & Mean & SD & \\
\hline \multirow[t]{4}{*}{ Position } & Staff & 1076 & 78.7 & 14.69 & 5.12 & $*$ \\
\hline & Sub-head nurse & 161 & 14.0 & 14.31 & 4.90 & \\
\hline & Head nurse & 80 & 5.8 & 13.29 & 4.62 & \\
\hline & No answer & 21 & 1.5 & - & - & \\
\hline \multirow[t]{6}{*}{ Shift type } & No shifts & 202 & 14.8 & 13.88 & 4.86 & $\dagger$ \\
\hline & Two shifts & 621 & 45.4 & 14.72 & 5.16 & \\
\hline & Three shifts & 481 & 35.2 & 14.75 & 5.10 & \\
\hline & Sometimes night duty & 52 & 3.8 & 14.06 & 4.49 & \\
\hline & Only night duty & 1 & 0.1 & - & - & \\
\hline & No answer & 11 & 0.8 & - & - & \\
\hline \multirow[t]{5}{*}{ Over time per month } & None & 83 & 6.1 & 13.41 & 4.87 & *** \\
\hline & $\leq 1-10$ hours & 695 & 50.8 & 14.30 & 5.02 & \\
\hline & $11-20$ hours $\geq$ & 355 & 26.0 & 14.92 & 5.09 & \\
\hline & $\geq 21$ hours & 200 & 14.6 & 15.61 & 5.19 & \\
\hline & Unknown & 35 & 2.6 & - & - & \\
\hline \multirow[t]{8}{*}{ Work section } & Mixed ward & 996 & 72.8 & 14.58 & 5.09 & \\
\hline & Outpatient & 96 & 7.0 & 14.60 & 4.83 & \\
\hline & ICU & 97 & 7.1 & 14.68 & 5.03 & \\
\hline & Emergency section & 5 & 0.4 & 18.60 & 4.82 & \\
\hline & Operating theater & 76 & 5.6 & 15.11 & 5.28 & \\
\hline & Home care & 29 & 2.1 & 12.83 & 4.69 & \\
\hline & Administrative department & 22 & 1.6 & 14.95 & 5.36 & \\
\hline & No answer & 47 & 3.4 & - & - & \\
\hline \multirow[t]{5}{*}{ Ward assignment preference } & Dissatisfied (the ward not as desired) & 194 & 14.2 & 17.58 & 4.60 & $* *$ \\
\hline & Dissatisfied (the ward as desired) & 230 & 16.8 & 17.59 & 3.88 & \\
\hline & Satisfied (the ward not as desired) & 392 & 28.7 & 13.95 & 4.92 & \\
\hline & Satisfied (the ward as desired) & 515 & 37.6 & 12.57 & 4.75 & \\
\hline & No answer & 37 & 2.7 & - & - & \\
\hline \multicolumn{7}{|c|}{ Presence of someone providing assistance in the workplace } \\
\hline \multirow[t]{3}{*}{ Other occupation } & Yes & 264 & 19.3 & 13.75 & 5.12 & $* *$ \\
\hline & No & 1095 & 80.0 & 14.79 & 5.63 & \\
\hline & No answer & 9 & 0.7 & - & - & \\
\hline \multirow[t]{3}{*}{ Junior } & Yes & 576 & 42.1 & 13.96 & 5.11 & ** \\
\hline & No & 783 & 57.2 & 15.05 & 5.27 & \\
\hline & No answer & 9 & 0.7 & - & - & \\
\hline \multirow[t]{3}{*}{ coworkers } & Yes & 767 & 56.1 & 14.39 & 5.13 & $\dagger$ \\
\hline & No & 592 & 43.3 & 14.84 & 5.03 & \\
\hline & No answer & 9 & 0.7 & - & - & \\
\hline \multirow[t]{3}{*}{ Senior } & Yes & 949 & 69.4 & 14.23 & 5.09 & $* *$ \\
\hline & No & 410 & 30.2 & 15.40 & 5.00 & \\
\hline & No answer & 9 & 0.7 & - & - & \\
\hline \multirow[t]{3}{*}{ Supervisor } & Yes & 570 & 41.7 & 13.17 & 5.01 & $* *$ \\
\hline & No & 789 & 57.7 & 15.61 & 4.90 & \\
\hline & No answer & 9 & 0.7 & - & - & \\
\hline \multirow[t]{5}{*}{ Commuting time } & Within 30 minutes & 994 & 72.7 & 14.50 & 5.09 & \\
\hline & $31-60$ minutes & 283 & 20.7 & 14.69 & 5.13 & \\
\hline & $61-90$ minutes & 77 & 5.6 & 14.99 & 4.96 & \\
\hline & Over 91 minutes & 12 & 0.9 & 15.33 & 5.45 & \\
\hline & No answer & 2 & 0.1 & - & - & \\
\hline \multirow[t]{5}{*}{ Enough care supplies } & Disagree & 128 & 9.4 & 17.05 & 4.92 & $* *$ \\
\hline & Somewhat disagree & 440 & 32.2 & 15.47 & 4.81 & \\
\hline & Somewhat agree & 607 & 44.4 & 13.91 & 4.89 & \\
\hline & Agree & 187 & 13.7 & 12.89 & 5.45 & \\
\hline & No answer & 6 & 0.4 & - & - & \\
\hline
\end{tabular}

$(\beta=0.09)$ was a related significant factor for high intention to leave for nurses. For organizational factors, the type of hospital and intention to leave were related $(\beta=-0.07)$, and the regional medical care hospital had lower mean intention to leave scores than the advanced treatment hospital (Table7). 
Table3. Correlation between the continuous variables and the total intention to leave score

\begin{tabular}{|c|c|c|c|c|c|c|c|c|}
\hline & & $\begin{array}{c}\text { Participants } \\
\text { N }\end{array}$ & Mean & $\mathrm{SD}$ & Min & Max & $\begin{array}{l}\text { Correlation } \\
\text { coefficient }\end{array}$ & \\
\hline Age (years) & & 1368 & 36.8 & 10.18 & 21 & 64 & -0.095 & $* *$ \\
\hline Experience as a nurse (years) & & 1368 & 13.4 & 9.65 & 1 & 45 & -0.057 & $*$ \\
\hline Striving for Work-Life balance & & 1368 & 37.4 & 8.41 & 11 & 66 & -0.390 & $* *$ \\
\hline (6 - 66 points; S-WLB is high as the high score) & & & & & & & & \\
\hline \multirow{3}{*}{$\begin{array}{l}\text { Sense of Coherence } \\
\text { (13 - } 91 \text { points; SOC is high as the high score) } \\
\text { Maslach Burnout Inventory-General Survey } \\
\text { (sub-scale total scores / each item; MBI - GS sub- } \\
\text { scale is high as the high score) }\end{array}$} & $\begin{array}{l}\text { Total } \\
\text { score }\end{array}$ & 1368 & 51.4 & 9.82 & 16 & 91 & -0.454 & $* *$ \\
\hline & Cy (5) & 1368 & 2.4 & 1.48 & & & 0.569 & $* *$ \\
\hline & PE (6) & 1368 & 2.2 & 1.14 & & & -0.157 & $* *$ \\
\hline \multirow{2}{*}{$\begin{array}{l}\text { The percentage of WLB in a day } \\
\text { (Higher points is the high work percentage) }\end{array}$} & reality & 1363 & 4.2 & 1.33 & & & 0.214 & $* *$ \\
\hline & ideal & 1360 & 2.7 & 1.00 & & & -0.087 & \\
\hline
\end{tabular}

$* 0.01<P<0.05, * * P<0.01 . \mathrm{SD}$, standard deviation

Min, minimum. Max, maximum

\section{DISCUSSION}

\section{A. Institutions and participants}

There is a report that the number of nursing staff [1] who is 35 to 39 years old is the largest, and that the male-female ratio in Japan is 1:14. The age distribution and male-female ratio of the respondents of this study are very similar, and close to that of nurses of general hospitals.

The adjusted $R^{2}$-coefficient for the related factors in the present study was 0.45 . As for the interpretation of the coefficient of determination, the adjusted $R^{2}$-coefficient of > 0.20 is sufficient in some instances, as social survey data contain much noise or is measuring human consciousness or behavior [30,31]. This allows concluding that the present study provides meaningful results with good predictive accuracy.

The intention to leave score for the study participants was the highest for those with clinical experience of 2 or 3 years, followed by $4,5,6$, and 7-10 years, and the lowest scoring group was 1 st year nurses. Previous studies also reported the intention to leave for 3 to 5 years of experience is high [32] similar to the results of this study. In addition, it may be inferred that the low intention to leave score for first year nurses in this study is a result of training of newly graduated nurses achieving some effect in hospitals [1]. However, the length of clinical experience is not correlated with the intention to leave, and it is necessary to consider the daily life situation and organizational culture background.

Table 4. Way of thinking towards work and the total intention to leave score

\begin{tabular}{|c|c|c|c|c|c|c|c|}
\hline \multirow[t]{2}{*}{ Variables } & & \multicolumn{2}{|c|}{ Participants } & \multicolumn{2}{|c|}{$\begin{array}{l}\text { Total Intention to leave } \\
\text { score }\end{array}$} & \multirow[t]{2}{*}{$\begin{array}{c}\mathrm{P}- \\
\text { value }\end{array}$} & \multirow{2}{*}{$\mathbf{N}=1$} \\
\hline & & $\mathrm{N}$ & $(\%)$ & Mean & $\mathrm{SD}$ & & \\
\hline \multirow[t]{2}{*}{ Suitability as a nurse } & Not at all & 735 & 53.7 & 15.69 & 4.85 & \multirow[t]{2}{*}{0.000} & \multirow[t]{2}{*}{$* *$} \\
\hline & Very much so & 633 & 46.2 & 13.29 & 5.05 & & \\
\hline \multirow[t]{2}{*}{ Feeling of being member of the organization } & Not at all & 577 & 42.1 & 16.13 & 4.86 & \multirow[t]{2}{*}{0.000} & \multirow[t]{2}{*}{$* *$} \\
\hline & Very much so & 791 & 57.8 & 13.44 & 4.97 & & \\
\hline \multirow[t]{2}{*}{ Salary satisfaction } & Not at all & 939 & 68.6 & 15.21 & 4.92 & \multirow[t]{2}{*}{0.000} & \multirow[t]{2}{*}{$* *$} \\
\hline & Very much so & 429 & 31.4 & 13.18 & 5.17 & & \\
\hline \multirow[t]{2}{*}{ Family understanding towards work } & Not at all & 223 & 16.3 & 15.39 & 4.69 & \multirow[t]{2}{*}{0.006} & \multirow[t]{2}{*}{$* *$} \\
\hline & Very much so & 1145 & 83.7 & 14.42 & 5.15 & & \\
\hline \multirow{2}{*}{ Easily finding new workplace } & Not at all & 688 & 50.3 & 14.55 & 5.04 & \multirow[t]{2}{*}{0.813} & \\
\hline & Very much so & 688 & 49.7 & 14.61 & 5.13 & & \\
\hline \multirow[t]{2}{*}{ Hardship in the life after resignation } & Not at all & 680 & 40.0 & 15.12 & 5.05 & \multirow[t]{2}{*}{0.001} & \multirow[t]{2}{*}{$* *$} \\
\hline & Very much so & 547 & 60.0 & 14.22 & 5.08 & & \\
\hline
\end{tabular}

** $P<0.01$, according to the $t$ - test. SD, standard deviation. 
Table 5. Perception of the workplace and the total intention to leave score

\begin{tabular}{|c|c|c|c|c|c|c|c|}
\hline \multirow[t]{2}{*}{ Variables } & & \multicolumn{2}{|c|}{ Participants } & \multicolumn{2}{|c|}{$\begin{array}{c}\text { Total Intention to leave } \\
\text { score }\end{array}$} & \multirow[t]{2}{*}{$\begin{array}{c}\mathrm{P}- \\
\text { value }\end{array}$} & -1500 \\
\hline & & $\mathrm{N}$ & $(\%)$ & Mean & $\mathrm{SD}$ & & \\
\hline \multirow[t]{2}{*}{ Approval in the workplace } & Not at all & 645 & 47.1 & 16.09 & 4.73 & 0.000 & $* *$ \\
\hline & Very much so & 723 & 52.9 & 13.22 & 5.01 & & \\
\hline \multirow[t]{2}{*}{ Opportunities to demonstrate ability } & Not at all & 637 & 46.6 & 16.07 & 4.78 & 0.000 & $* *$ \\
\hline & Very much so & 731 & 53.4 & 13.27 & 4.98 & & \\
\hline \multirow[t]{2}{*}{ Request more than abilities } & Not at all & 635 & 46.4 & 14.38 & 5.19 & 0.191 & \\
\hline & Very much so & 733 & 53.6 & 14.74 & 4.99 & & \\
\hline \multirow[t]{2}{*}{ Benefits are good } & Not at all & 736 & 53.8 & 15.29 & 4.94 & 0.000 & $* *$ \\
\hline & Very much so & 632 & 46.2 & 13.75 & 5.13 & & \\
\hline \multirow[t]{2}{*}{ Working with role consciousness } & Not at all & 675 & 49.3 & 15.85 & 4.73 & 0.000 & $* *$ \\
\hline & Very much so & 693 & 50.7 & 13.34 & 5.12 & & \\
\hline \multirow[t]{2}{*}{ Cooperation in the workplace } & Not at all & 505 & 36.9 & 16.29 & 4.72 & 0.000 & $* *$ \\
\hline & Very much so & 863 & 63.1 & 13.57 & 5.03 & & \\
\hline \multirow[t]{2}{*}{ Medical accidents easy to occur } & Not at all & 629 & 46.0 & 13.76 & 4.88 & 0.000 & $* *$ \\
\hline & Very much so & 739 & 54.0 & 15.27 & 5.16 & & \\
\hline \multirow[t]{2}{*}{ Security in case of medical accidents } & Not at all & 805 & 58.8 & 15.47 & 4.80 & 0.000 & $* *$ \\
\hline & Very much so & 563 & 41.2 & 13.30 & 5.43 & & \\
\hline \multirow[t]{2}{*}{ Openness in discussions in the workplace } & Not at all & 793 & 58.0 & 15.79 & 4.88 & 0.000 & $* *$ \\
\hline & Very much so & 575 & 42.0 & 12.90 & 4.88 & & \\
\hline \multirow[t]{2}{*}{ High turnover rate } & Not at all & 572 & 41.8 & 13.39 & 4.86 & 0.000 & ** \\
\hline & Very much so & 796 & 58.2 & 15.43 & 5.07 & & \\
\hline \multirow[t]{2}{*}{ Ease of obtaining desired holidays } & Not at all & 525 & 38.4 & 16.12 & 4.81 & 0.000 & $* *$ \\
\hline & Very much so & 843 & 61.6 & 13.61 & 5.02 & & \\
\hline \multirow[t]{2}{*}{ Providing sufficient patient care } & Not at all & 805 & 58.8 & 15.58 & 4.80 & 0.000 & ** \\
\hline & Very much so & 563 & 41.2 & 13.14 & 5.15 & & \\
\hline
\end{tabular}

** $P<0.01$, according to the $t$ - test. SD, standard deviation.

Table 6. Organizational factors and the total intention to leave score

\begin{tabular}{|c|c|c|c|c|c|}
\hline \multirow[t]{2}{*}{ Organizational factors } & \multicolumn{2}{|c|}{ Number } & \multicolumn{3}{|c|}{ Total intention to leave score } \\
\hline & itals & participants & Mean & SD & \\
\hline Size of the city of the hospital location & & & & & *** \\
\hline A small-sized city with a population of less than 100,000 & 4 & 291 & 14.61 & 4.57 & \\
\hline A medium-sized city with a population between 100,000 and 500,000 & 4 & 726 & 14.21 & 5.07 & \\
\hline A big city with a population of more than 500,000 & 1 & 351 & 15.39 & 5.33 & \\
\hline Types of hospital & & & & & $* *$ \\
\hline A general hospital & 4 & 220 & 14.61 & 4.57 & \\
\hline A regional medical care hospital etc. & 2 & 455 & 13.97 & 5.09 & \\
\hline An advanced treatment hospital etc. & 3 & 693 & 14.97 & 5.20 & \\
\hline Average number of days of hospitalization & & & & & $* *$ \\
\hline$\leq 10$ days & 1 & 351 & 15.39 & 5.33 & \\
\hline $11-15$ days & 5 & 764 & 14.22 & 5.00 & \\
\hline$\geq 16$ days & 3 & 253 & 14.52 & 4.87 & \\
\hline $\begin{array}{l}\text { Bed number of the hospital } \\
\text { Fewer than } 99 \text { beds }\end{array}$ & 1 & 27 & 13.74 & 4.86 & \\
\hline $100-199$ beds & 3 & 193 & 14.73 & 4.53 & \\
\hline 200-299 beds & - & - & - & - & \\
\hline 300-399 beds & 1 & 215 & 14.23 & 5.07 & \\
\hline $400-499$ beds & 4 & 933 & 14.65 & 5.20 & \\
\hline
\end{tabular}

** $P<0.01$, According to the one - way ANOVA. SD, standard deviation. 
Table 7. Factors related to intention to leave from the stepwise multiple regression analysis

\begin{tabular}{|c|c|c|}
\hline Explanatory variables & $\begin{array}{c}\text { Standardized partial } \\
\text { regression coefficient } \beta\end{array}$ & $P$ - value \\
\hline MBI - GS (Cynicism) $\dagger$ & 0.300 & 0.000 \\
\hline Satisfaction after desired assignment $\$$ & -0.193 & 0.000 \\
\hline Satisfaction after not desired assignment $§$ & -0.128 & 0.000 \\
\hline $\mathrm{SOC} \dagger$ & -0.117 & 0.000 \\
\hline MBI - GS (Exhaustion) $\dagger$ & 0.109 & 0.000 \\
\hline This hospital has a high turnover rate II & 0.093 & 0.000 \\
\hline Hardship in the life after resignation II & -0.090 & 0.000 \\
\hline $\mathrm{S}-\mathrm{WLB} \dagger$ & -0.078 & 0.003 \\
\hline Security in case of medical accidentsII & -0.068 & 0.005 \\
\hline Type of hospitals $\uparrow \dagger$ & -0.068 & 0.002 \\
\hline Openness of discussions in the workplaced[ & -0.069 & 0.006 \\
\hline Actual percentage of WLB +4 & 0.050 & 0.030 \\
\hline
\end{tabular}

\begin{tabular}{|c|c|}
\hline $\mathrm{R} 2$ - value & 0.453 \\
\hline Adjusted R2 - value & 0.448 \\
\hline
\end{tabular}

\section{B. Factors related to intention to leave of nursing staff}

From the result of the multiple regression analysis, the factors related to intention to leave in this study were burnout (cynicism, exhaustion) which was high in explanatory rate, satisfaction at desired assignment, and the SOC. The S-WLB, which was the object of this study, was also related to the intention to leave. Regarding burnout, many studies have shown a relationship between intention to leave or turnover in nurses $[4,5,6]$, and much research has been reported. Therefore, in this study, burnout was treated as a confounding factor of intention to leave, and a multiple regression analysis was carried out.

The nurses who reported that the assigned ward was what they hoped for, and that they were satisfied with the ward although it was different from what they hoped for showed higher intention to leave than those who reported that they were dissatisfied with the ward assignment either as hoped for or not. Suzuki et al. [8] have reported the rapid turnover behavior of novice nurses who are dissatisfied that the assigned ward was not what they hoped for. In addition, mental suffering, work stress [9] and lack of supporting supervisors $[9,10,33]$ is a factor in the intention to leave and it is conceivable that inconsistencies between desired assignment and workplace satisfaction after assignment promotes intention to leave.
For SOC, it has been reported that newly graduated nurses with low SOC scores have high intention to leave scores [34], and the newly graduated nurses of this study suggest a similar result. In addition, as the nursing staff with 2 or 3 years experience has a strong intention to leave, and the longer clinical experience shows this to be higher, the intention to leave score tends to gradually decline. The SOC has a tendency to rise with age [22,24]. Even at ages other than newly graduated nurses, if their SOC level is high, it is a possibility that the intention to leave becomes low. It is necessary to raise SOC and undertake measures for nursing staff with low SOC.

With regard to S-WLB, nursing staff with high S-WLB tended to report a lower intention to leave. Tanabe et al., [20] stated the necessity of improving the evaluation on the balance between work and non-work life in nurse intention to leave employment. Nursing staff have recognized how to work properly in modern society and then need the ability to strive for WLB themselves. In this study, rather than evaluating the recognition of WLB, we thought that the ability to adjust WLB would not increase the intention to leave and we used the $\mathrm{S}$ WLB scale as an explanatory variable. The S-WLB can evaluate the ability of a nurse to consult to improve WLB and the ability to control time and health as a resident citizen which may help lower the intention to leave score. In this study, for nursing staff with high S-WLB, it is a possible that the 
intention to leave may be lowered, and it is desirable to improve S-WLB scores to prevent these nurses from discontinuing employment.

As mentioned above, we identified the relevance of the turnover intention at the individual level, when considering the possibility that individual turnover intentions differ and depend on the organizational background; additionally, analyzing the organizational factor as a variable, this could explain the differences in the intention to leave/remain score. A nationwide survey showed that the turnover rate of small hospitals in urban areas is high [1]. In this study, the regional medical care hospitals with a small number of beds had a lower mean intention to leave score than the large hospital and advanced treatment hospitals. In addition, in the nationwide survey on early turnover the target was experienced and newly employed nurses, here the regional medical care hospitals showed a higher turnover intent than the general hospitals, which is different from this study [35]. In this study, it was shown that the nurse perceptions of the work environment that the secured feelings arise when a medical accident happens, that the workplace offers an opportunity for open discussion, and that the hospital has a high turnover rate are related to the intention to leave. It is difficult to solve the problem of the intention to leave due to the complicating background involving organizational, workplace, and nurses' individual factors. In addition, the relationship between actual turnover and intention to leave is not clear, and it is desirable that further research into this be undertaken.

\section{Study limitations}

This study was conducted through cooperation with nine hospitals in one region of Japan and generalization of the results would be limited by that. Additionally, as this was a cross sectional study, no causal inferences can be made. The background to the intention to leave a workplace or profession involves complex issues with individuals, the workplace environment, and the organizations, and it is necessary to consider these differences in measures to prevent turnover. In future studies, it is necessary to identify the cause by a longitudinal study.

\section{CONCLUSIONS}

In this study, full-time nurses with low S-WLB and low SOC levels showed high intention to leave. It was found that satisfaction of being able to work in a desired assignment is also a significant factor leading to higher intention to leave scores. In establishing a workplace for nursing staff, it is necessary to pay attention to the period of the transition from being newly graduated as a nurse to becoming an experienced nurse, and to consider individual S-WLB and SOC functions. It is also important to recognize the influence of workplace environment and support arrangements that make it possible to properly evaluate workplace satisfaction after placement in an organization.

\section{ACKNOWLEDGMENT}

We wish to thank all the nurses, directors and nursing department staff for their help in participating in the present study.

\section{REFERENCES}

[1] Japanese Nursing Association, "Heisei 28 nursing relations statics collection (Heisei 28 nen kango kankei toukei shiryousyu nihon kango kyoukai syuppankai hensyu in Japanese),"_Accessed June 22, 2017.

[2] M. Tei-Tominaga, A. Miki, and K. Fujimura, "A cross-sectional study of factors associated with intentions to leave among newly graduated nurses in eight advanced treatment hospitals: job stressors, job readiness, and subjective health status" Japanese society of public health, vol. 56 (5), pp. 301-311, 2009.

[3] R. Watanabe, M. Arakida, and S, Suzuki, "Individual and organizational factors influencing turnover among young nurses: comparison between one and five years of experience (wakate kangoshi no risyoku ikou ni kanren suru kojin youin to soshiki youin no kento in Japanese)," Journal of Japan academy of nursing science, vol. 30 (1), pp. 55-61, 2010.

[4] S. A. Boamah, and H. Laschinger, "The influence of areas of worklife fit and work-life interference on burnout and turnover intentions among new graduate nurses" Journal of nursing manegemant, vol. 24, E164E174, 2016.

[5] T.Ohue, M. Moriyama, and T. Nakaya, "Examination of a cognitive model of stress, bournout, and intention to resign for Japanese nurses," Japan Journal Nursing Science, vol. 8, pp. 76-86, 2011.

[6] H. Furuya, and F. Tani, "The bournout process model from the occurrence through intention to quit among nurses (kangoshi no bournout seiki kara risyoku ganbou ni itaru process model no kento in Japanese)," Journal of Japan academy of nursing science, vol. 28 (2), pp. 55-61, 2008.

[7] K. Uchino, and R. Shimada, “A literature review of turnover among new graduate nurses in Japan (Honpou ni okeru shinnjin kanngoshi no risyoku ni tsuiten no bunkenkenkyu in Japanese)" Health sciences of mind and body, vol. 11 (1), 18-23, 2015.

[8] E.Suzuki, I.Itomine, Y.Kanoya, T.Katsuki S.Hiroi, and C.Sato, "Factors Affecing Rapid Turnover of Novice Nurses in University Hospitals" Jounal of occupational health, vol. 48, 49-61, 2006.

[9] M. Tei-Tominaga, and A. Miki, "A longitudinal study of factors associated with intention to leave among newly graduated nurses in eirht advanced treatment hospitals in Japan," Industrial Health, vol. 48, pp. 305-316, 2010.

[10] Y. Saijo, E. Yoshioka, Y. Kawanishi, Y. Nakagi, T. Itoh, and T. Yoshida "Relationships of job demond, job control, and social support on intention to leave and depressive symptoms in Japanese nurses," Industrial Health, vol. 54, pp. 32-41, 2016.

[11] M. Nanba, Y. Yuki, and K. Ninomiya, "Organizational Climate, Organizational Commitment and Intention to Leave among Hospital New Nurses in Japan," Bulletin of Faculty of Health and Welfare Sciences, Okayama Prefectural University, vol. 19, pp.1-7, 2012.

[12] M. Nanba, Y. Yajima, K. Ninomiya, K. Takai, "The relationship between job and organizational characteristics, organizational commitment, and intention tonleave organization among japanese nurses (Kangoshi no soshiki • syokumu tokusei to soshiki komittomento oyobi risyokuikou no kanren in Japanese)," The Journal of Japan Academy of Health Sciences, vol. 12 (1), pp. 16-24, 2009.

[13] Ya-Wen Lee, Yu-Tzu Dai, and L. L. Maccreary, "Quality of work life as a predictor of nurses' intention to leave units, organisations and the profession" Journal of Nursing Management, vol. 23, pp. 521-531, 2015.

[14] H.Takahashi, S. Kitano, H. Ishikawa, Y. Kida, and N. Nakada, Y. Yamazumi, and F. Yasukata, "Intervention and efficacy of new graduate nurses turnover prevention -a stress management perspective(seishinnka byouin ni okeru shinnjinn kanngoshi no risyoku boushi ni taisuru kainyu to sono kouka in Japanese)," The Japanese Phychiatric Nursing Society, vol. 54 (2), pp. 161-164, 2011.

[15] E. Sakata, M. Megumi, Y. Asajima, S. Nakayama, and E. Ono, 'Evaluation and assignment of new graduate nurses' peer support traning in three months after new hireing (nyuusyokugo sankagetsu no shinjin kangoshi pia sapoto kensyu no hyouka to kadai in Japanese)," Bulletin of Osaka Medical Nursing College, vol. 17, pp. 34-38, 2011. 
[16] The Japan Institute for Labour Policy and Training, "Heisei-23 Survey on mental healthcare countermeasures in the workplace (Heisei 23 nendo syokuba ni okeru mental health care taisaku ni kansuru cyosa in Japanese)," http://www. jil. go. jp/, Accessed August 7, 2015

[17] Japan Federation of Medical Worker's Unions, "Results of labor situation survey of nursing staff in 2013 (2013 ennndo kango syokuin no roudou jittai cyousa kekka in Japanese)," http://irouren.or.jp/research, Accessed March 11, 2016.

[18] H. Kawamura, and E. Suzuki, "A Study of relationships between work life balance and burnout in hospital nurses (byouin ni kinmu suru kangosyoku no work life balance to bournout tono kanren in Japanese),' Journal of Japan Academy of Nursing Sciences, vol. 34, pp. 131-141, 2014

[19] K. Chikasue, "Relationship between worl-life balance and occupational career maturity among nurses to work in a hospital while rasing children (kosodate wo shinagara byouin ni kinmu suru kangosyoku no work life balance to syokugyou career seijyuku tono kanren in Japanese)," The Journal of the Japan Academy of nursing administration and Policies, Vol. 19 (2), pp. 67-75, 2015

[20] T. Tanabe, and H. Okamura, "An investigation of the factors related to th intention of nurses to leave their profession: based on a survey of nurses working in palliative care units, (kangoshi no risyoku ikou ni kanren suru youin no kentou -kanwa care byoutou ni okeru cyousa kekka wo motoni- in Japanese)" Palliative Care Research, Vol. 6 (1), pp. 126132, 2011.

[21] A. Antonovsky, "Unraveling the Mystery of Health: How People Manage Stress and Stay Well (Kenko-no-nazo-wo-toku,)," Trans Y. Yamazaki, K. Yoshii, Yushindo Kobunsha, Tokyo, 1987.

[22] M. Matsuo, and E. Suzuki, "Factors related to sense of coherence (SOC) among nurses in Japan," $5^{\text {th }}$ Annual Worldwide Nursing Conference (WNC2017), pp. 246-258, 2017.

[23] E. Yoshida, K. Yamada, H. Shibataki, and I. Morioka, "Relationship between sense of coherence and stress reactions among nurses in a hospital (Kangoshi no sense of coherence to stress hanno tono kanren in Japanese)," Japan society of Nursing Research, vol. 36 (5), pp. 25-33, 2013.

[24] K. Urakawa, K. Yokoyama, and H. Itoh, "Sense of coherence is associated with reduced psychological responses to job stressors among Japanese factory workers," BMC Research Notes, 5, 247, 2012

[25] M.Matsuo, M.Takano, Y.Takayama, and T. Machida, "Relationships between striving for work-life balance, sense of coherence and intention to leave among nurses in Japan." $6^{\text {th }}$ Annual Worldwide Nursing Conference (WNC2018),pp183-192,2018

[26] M. Tei-Tominaga, and Y. Yamazaki, "The impact of work and organizational characteristics on the health status, job dissatisfaction and turnover intentions od workers in an information service industry (jyoho servis sangyo ni okeru roudo syokuba kankyo tokuse ga roudousya no shinshin no kenkou, syokumu fumanzoku oyobi risyoku ikou ni oyobosu eikyo in Japanese)," Jounal of Occupational Health, vol. 45, pp. 20-30, 2003

[27] Y. Yamazaki, T. Togari, and J. Sakano (Eds), "Introduction to the sense of coherence in the autogenic model (Stress taisyo nouryoku SOC in Japanese)," Yushindo Kobunsya, Tokyo p. 5-7, 2008.

[28] K. Kitaoka-Higashigushi, S. Masuda, K. Ogino, H. Nakagawa, "The Maslach burnout inventory-general survey (MBI-GS) and the Japanese version (burnout sokutei syakudo Maslach Burnout Inventory-General Survey (MBI-GS) no gaiyou to nihon ban ni tsuite in Japanese)," hokuiriku Journal of Public Health, Vol. 37(2), pp. 34-40, 2011.

[29] C. Maslach, SE. Jackson, MP. Leiter, "Maslach bornout inventory manual. $3^{\text {rd }}$ edition. Palo Alto CA, consulting psychlogists press, 1996.

[30] Y. Murase, H. Takada, and T. Hirose, "Multiple analysis with SPSS (1 ${ }^{\text {st }}$ ed) (SPSS niyoru tahenryo kaiseki in Japanese)," Ohmsha, Tokyo, p.183, 2007.

[31] K. Nakayama, "Introduction to multivariate analysis for nursing studies (kangogaku no tameno tahenryo kaiseki nyumon in Japanese)," Igakusyoin, Tokyo, p. 101.

[32] M. Ikeda, M. Hirano, M. Sakaguchi, K. Mori, A. Tamada, "The effect of nurses' quality of life (QOL) and and self-efficacy on their intention to quit," Journal of Japan academy of nursing science, vol. 31 (4), pp. 46 54, 2011.

[33] D. R. de Oliveira, R. H. Griep, L. F. Portela, and L. Rotenberg, "Intention to leave profession, Psychosocial environment and self-rated health among registered nurses from large hospitals in Brazil: a crosssectional study,”BMC Health Services Research, 17:21, 2017.

[34] Y. Yamazumi, and F. Yasukata, "Research on the sense of coherence (SOC) and influence factors of newly graduated nurses (Shinsotsu kangoshi no SOC to eikyou youin ni kansuru kenkyu in Japanese)," Journal of Japan Academy Nursing Education, vol. 21 (2), pp. 13-22, 2012

[35] M. Ito, H. Mitsunaga, and T.Ibe, "Survey to compare experienced versus new nurses' employment and turnover in Japanese hospitals (byouinn niokeru kisotsu kangoshi no saiyou to souki risyoku ni kansuru zenkoku cyousa -shinsotsu saiyousya tono hikaku karano kousatsu - in Japanese)," Journal of Japan Academy of Nursing Sciences, vol. 37, pp. 254-262. 